\title{
REASONS AND EFFECTS OF THE ROMANIAN LABOUR FORCE MIGRATION IN EUROPEAN UNION COUNTRIES
}

\author{
Ramona Frunză \\ "Alexandru Ioan Cuza" University of Iaşi \\ Liviu George Maha \\ “Alexandru Ioan Cuza” University of Iaşi \\ Claudiu Gabriel Mursa \\ "Alexandru Ioan Cuza" University of Iaşi
}

\begin{abstract}
In the European Union countries and neighboring regions, the expansion will produce a redistribution of the labour force between industries and countries. After the Romania's adhesion to the European Union, the need for an increased productivity, the lack of capital, the competition on the EU market and the low wages have concurred to the intensification of the migration process of the labour force, especially to the West European countries. As example, from over two millions of Romanians working abroad (almost $10 \%$ from total population), 40\% have chosen to work in Italy, $18 \%$ in Spain, 5\% in Germany.

In this context, the questions that appear refer to the following issues: Does a real possibility exist for the emigrants to join the active population of the destination country and being employed according to their competences? How many Romanians citizens continue to stay in a foreign country if their job is not proper with their professional skills? Which countries in European Union apply discriminations on its labour market? Do European Countries usually admit Romanian employees temporarily and expect them to leave in short time if they can't find a proper job? Which are the socio-economic effects of labour mobility on the Common Market of EU? Which are the forecasts concerning the labour mobility in the next years?

In our paper, we try to answer these questions and we also intend to make a comparative analysis concerning - what we consider - some of the most important challenges occurred in Romania's economy in the context of the mentioned migration process: the adoption of an economic growth model based on the increase of the employed population, the diminution of the discrepancies between our country labour market and the EU target established through Lisbon Strategy, the creation of a new structure of occupation with support in productivity growth and labour price.
\end{abstract}

Keywords: Romanian emigrants, labour market, European Union, migration effects

JEL Classification: F22, F24, F15 


\section{GENERAL ASPECTS}

European countries vary widely in the institutional structure of their education and training systems and labour markets in that different resources are provided to school-leavers entering into working life in many countries and these new job-seekers face varying institutional and economic contexts in labour markets. Institutional differences in both education and training systems and labour markets play a major role in explaining cross-national differences in the experiences of young people entering the labour market in European countries, even after accounting for the effects of variation in economic conditions and other unmeasured heterogeneity between countries and types of qualifications (Gangl, M., 2006). We should not forget that education is the main resource for obtaining employment for young people entering the labour market.

High economic growth and a vast labour exodus to Western Europe have created a labour shortage in many sectors of Romania's economy. As a result, growing wage pressures could have a negative impact on foreign direct investment, slowing the country's economic growth. Businesses in some sectors have difficulties in finding skilled workers, while facing rising labour costs. However, mounting wages and remittances from abroad has led to rising consumer demand (Drew, 2007).

Concerning our country, after the fall of the communist block in 1989, migration started to shape as a deflation phenomenon, a lot of people living the country in the first two years after the revolution. But it was not only until the mid 90's that abroad tourism and labour migration started to shape as a reality of Romania.

Nowadays, the mobility of people represents a normal and greatly mediated topic for the Romanian society. More and more people are choosing to spend their holidays abroad and a significant number of young people fulfil their desire to get in touch with other cultures by travelling, working or studying abroad. But the most important phenomenon for Romanian migration is represented by labour migration and it's implications for the society at large. Millions of Romanians have adopted this practice as a life strategy, and are hoping that the EU enlargement will help them in getting the status of legal workers in the Western countries of destination (as Italy, Spain, Great Britain, etc.). The implication that this mobility has on the Romanian political, social and economical system is of huge importance as less and less people are suffering from the closing of public industries (such as mines and industrial platforms for example - where entire cities and surrounding areas were employed) and they withdraw themselves from the system of social security of the state. 


\section{OVERVIEW OF THE ROMANIAN LABOUR MARKET}

In the latest years the labour market in Romania has suffered deep changes. There are two distinct stages to be found regarding the evolutions on the labour market in Romania after 1989. The first stage, which includes the period 1990-2003, is defined as a period of deep reorganization of the Romanian economy. It is characterized as a period of relatively high unemployment and the undertaken actions were directed mainly at limiting the unemployment and its harmful effects on the society. We consider that after 2005 the employment evolution heads towards a new crisis on the labour market, but its cause is not a high unemployment, but rather an offer dropping on the labour market. (Cindrea, 2007, pp. 25-28). The labour market is one of the important factors, especially for longer distance moves. Economic theory provides a characteristic for the migration decision that emphasizes the way that labour market considerations can influence migration decisions. In the simplest version of such a model, each person chooses to locate in the area where they will be most well-off.

Zaman (2004) analyses the dynamics of restructuring on the labour market by The Index of Employment Restructuring, The Rate of Unemployment Absorption and The Net Rate of Private Sector Expansion. He notes that the capacity of Romanian economy to absorb the unemployment is very modest because the private activities are insufficiently developed due to a major delay in market reforms aimed to effectively stimulate the private initiative. Romania has conducted its employment policies rather inconsistently and therefore the capacity of the economy to absorb the unemployment is very modest; moreover, the economy has destroyed more jobs than it created. This is the consequence of insufficient reforms aimed to stimulate growth: in 2003, the real GDP is still below its level recorded in 1990. The speed of private sector development is low compared to the rhythm at which the public sector is shrinking. As a result, the private sector looses continuously its efficiency because the privatization of public enterprises induced the phenomenon of sharing the inefficiency: the speed of restructuring the privatized firms is lower than the speed of privatization. Each year the public firms gain productivity by reducing the employment, but they loose efficiency over time, since the output produced by the remaining labour force is below its potential. In parallel, the private sector looses efficiency because of privatization, which brings excessive employment with the newly privatized firms. Over time, the output produced by an employee in the private sector is higher than the one produced by a state employee, which leads to an improvement of efficiency in case of private companies (Zaman, 2004, p.8)

According to J.P. Garson, although Europe is considered today more as an area of immigration and of acceptance of refugees, it also contributed in the past to migration flows, 
notably during the 19th century and up to the end of the 1960s (Garson, 2004, p.17). Recent trends show the ageing of European populations, which has rekindled the debate on migration as a way of increasing the working population at the beginning of the 21 st century. Several recent studies have shown, however, that immigration alone will not be sufficient to modify the demographic structures of those European countries most affected by population decline.

\section{MIGRATION PHENOMENON IN ROMANIA}

Migration is one of the most important factors affecting economic development in the $21^{\text {st }}$ century. (Hatton, 2001; Shields and Wheatley, 1998; Wheatley, 2001) By population (about 22 million inhabitants at the beginning of the millennium), Romania ranks the ninth in Europe. Like many other countries Romania is facing a population diminution, but its labour potential is still high and under-used. The gap in the demographic transition of over one decade between Romania and the European countries makes of Romania an (still) attractive source of younger, high-skilled and relatively cheaper labour force.

Romania faced, especially after 2005, a gradual decrease in the national labour resources, showing major imbalances by age group, which may equally cause demographic, economic and social problems. A society having less and less young people and more and more old people and being unable to ensure self-generation and necessary wealth becomes a pressure factor in the region with quite unpredictable consequences.

If we refer to the labour market and migration in Romania, we have to focus on the evolution of legislation in Romania. Romania's main objective in the post-communist period was the integration in the European Union, in other words the conformation to the acquis communitaire.

There has been progress in legislation after 2000 regarding:

- the aliens' regime in Romania;

- the statute and the regime of refugees in Romania;

- preventing and combating the trafficking in human beings;

- work permits.

Lower progress took place in the following legislation:

- the mutual recognition of degrees and qualifications;

- discrimination of EU citizens as compared the Romanians in getting a job Romania by giving priority to the Romanian citizens. 
Legislation regarding stay and work seems to be more a problem of contradictory regulations rather than strict enforcement. Legal status not only affects the relative migration costs and expected benefits but it also changes the underlying economic incentives. High economic growth and a vast labour exodus to Western Europe have created a labour shortage in many sectors of Romania's economy. As a result, growing wage pressures could have a negative impact on foreign direct investment, slowing the country's economic growth. Businesses in some sectors have difficulties in finding skilled workers, while facing rising labour costs. However, mounting wages and remittances from abroad has led to rising consumer demand.

Romanians are mostly going to work abroad in Italy and Spain, although those two countries imposed restrictions on Romanian workers, and another 10 European states opened their labour markets for Romanians and Bulgarians following the accession of the two countries to the European Union from January 1, 2007. Cyprus, the Czech Republic, Estonia, Finland, Latvia, Lithuania, Poland, Slovakia, Slovenia and Sweden decided to forego labour market restrictions. However, some 31 percent of Romanians who have emigrated went to work in Italy, and a further 17 percent to Spain. Other destinations for Romanian migrant workers are Germany ( 8 percent), the US (5 percent), and France (4 percent). Migration to those countries began 8-10 years ago and people have those destinations in mind. Some 2.5 million Romanians are currently working abroad, while about 11 percent of Romanians aged 18 to 59 are considering emigration - according to a study by EUbased NGO European Citizen Action Service (ECAS).

Most EU countries have introduced sector specific quotas for Romanian workers. The UK, for example, has allowed unlimited numbers of highly skilled workers and an annual quota of 19,750 blue collar workers for specific sectors. In order to tackle the labour crisis, the Romanian government is encouraging repatriation, while attracting workers from outside the EU to fill gaps in the labour market. Businesses are facing lower profits due to production losses and higher wages. Romania's current labour shortage results from the combined effects of the country's economic boom and mass exodus of labour migrants.

Romania has seen unprecedented economic growth, driven by FDI inflows, with an average growth of $6.0 \%$ between 2001 and 2006. Consequently, the number of job openings has increased amounting to 98,627 in the first quarter of 2007 ; 


\section{Graph 1 - Number of job vacancies vs. harmonized unemployment in Romania}

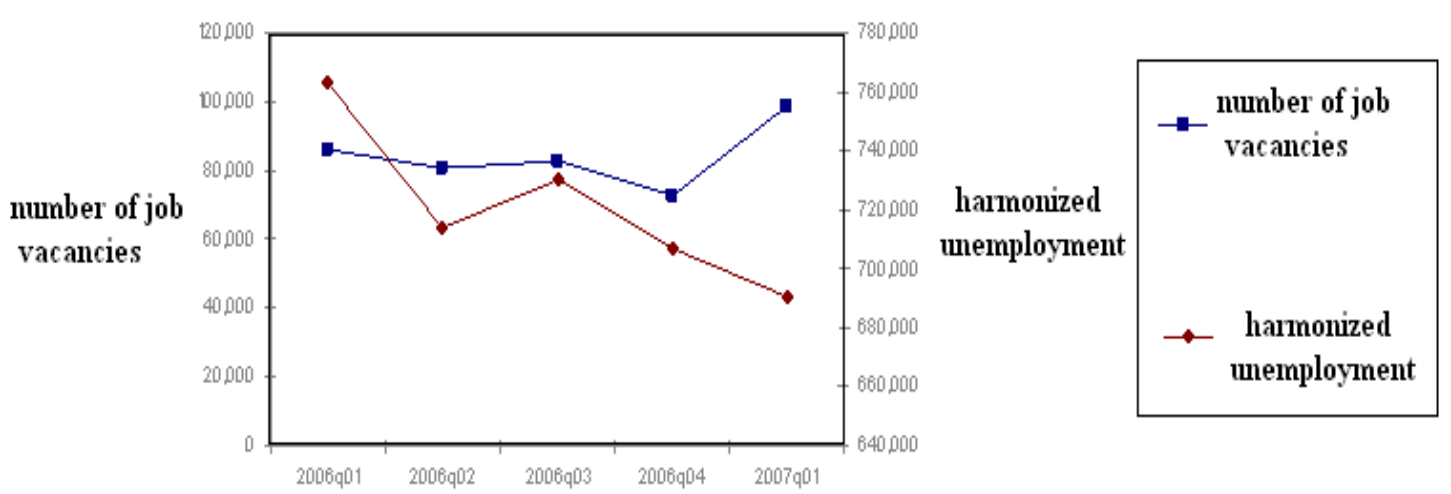

Source: Eurostat

Many Romanians opted to leave the country in order to work in Western Europe or the USA, where wages and the standard of living are higher. While the minimum wage in Romania amounted to $€ 114$ in the first quarter of 2007 , minimum wages in the UK and the USA were $€ 1,361$ and $€ 676$ respectively. Since 1989 Romania has lost between 2.0 and 2.5 million of its workforce. Considering Romania's population of 21.6 million in 2006, this is about $10 \%$ of the country's population.

The total value of money sent home by the Romanians who work abroad offers a good image about the amplitude of the migration phenomenon. Romania occupies the tenth place in the world, in a position of remittances drawn up by the World Bank and on the second place in the EU.

We can summarize the situation in this domain in the following terms:

- currently, over two million Romanians are working abroad:

- Romania's population decreased with 1.6 million of inhabitants between 1992 and 2006;

- the main countries in which the Romanians are working are Italy, Spain, Israel, Germany, Great Britain;

- the Romanians who work abroad will send this year 6.5 billion euros, a bigger sum compared to the previous year when the it reached 5.5 billion euros;

- Romanians' remittances represent $5.7 \%$ of the Gross Domestic Product.

\section{The profile of the Romanian emigrant}

In general, the Romanians who go abroad represent a competitive working force, well trained. The graduates from the higher education represent about $10-12 \%$ of the total of persons who had legally emigrated, and over a quarter of these are graduates from the high-school and post- 
high school education, according to the Demographical Decline Study of the Romanian Academy, of 2007. The emigrants with vocational and technical studies represent approximately $9 \%$, while the persons who have graduated only from the primary or secondary school, represent less than a third of the total of emigrants.

\section{Graph 2 - The education of Romanian emigrants}

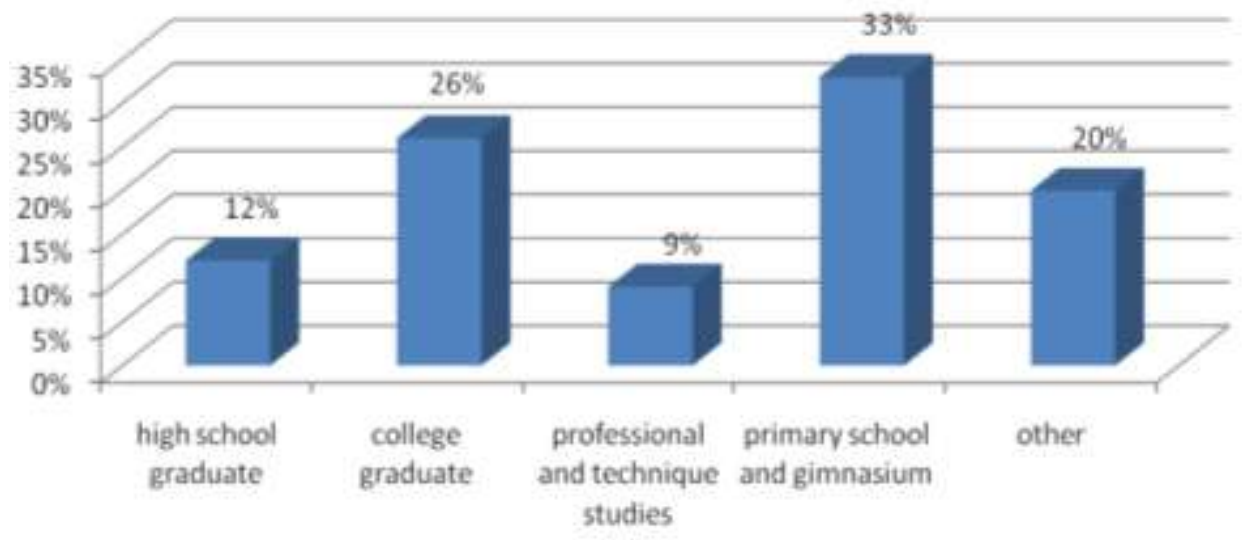

Source: Romanian Academy, http://www.standard.ro/articol_22973/special_

The Romanians' going abroad has manifested, in the '90s, as a phenomenon of intelligence exodus, as it was the migration of a highly qualified working force. In the first wave, the engineers, the architects, computer scientists, economists and teachers followed. In the last years, we have witnessed the massive migration of the unqualified working force or with medium qualifications, which made the employers talk more and more about an acute crisis of the working force regarding this segment. Currently, those who emigrate are the Romanians with positions for which there are very high salary discrepancies. The differences appear in constructions, agriculture and health. All these successive exportation waves have put an indirect pressure on the salaries, the Romanians winning more also because of the fact that the unemployment rate is extremely low (only $4 \%$ at the national level), in the absence of an important segment of population. 


\section{Graph 3 - The profession of Romanian emigrants}

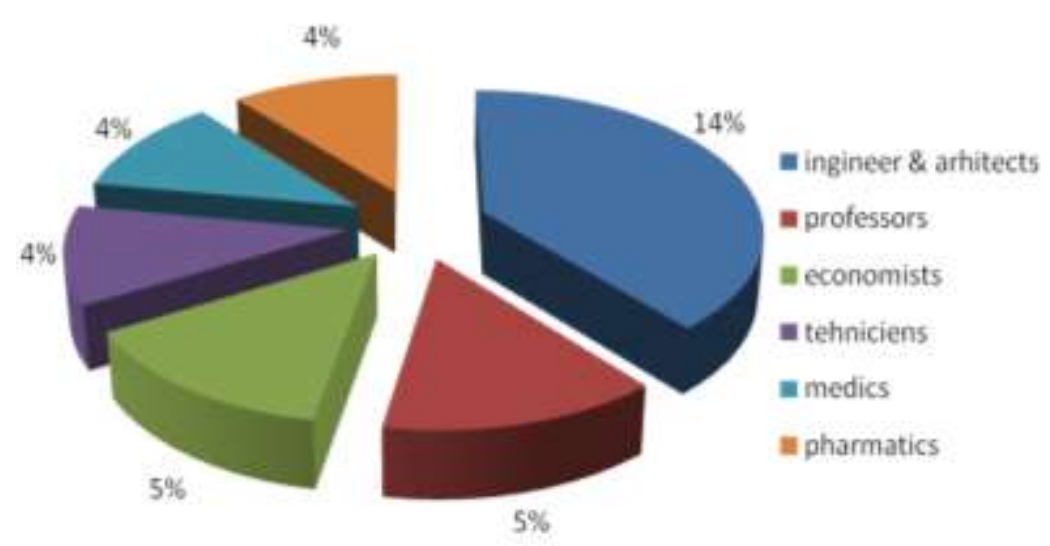

Source: Romanian Academy

Those involved in the legal emigrational movement mainly belong to three categories of working force. The first segment is represented by the highly qualified working force, from the age category of 25-40 years old, with competences in top fields of the science and technology and in some fields such as education and health. Then, there is the working force with a medium level of training, with specializations which cover the fields: constructions (Germany, Israel), health (Italy, USA, Switzerland), hotels, public alimentation (especially the Western market). Then there is the unqualified and semi-qualified working force - in activities from agriculture, salubrity, constructions (Spain, Portugal, Greece). According to the study mentioned, the migration is selective- in general, the youngsters and a valuable working force segment leave. The opening of the working market in Europe will continue to reduce the number of active persons, who remain to work in Romania. They especially emigrated from mono-industrial areas, in which there were many dismissals, and those included in such programs did not have the alternative of employment. They completed jobs beneath their level of training. 


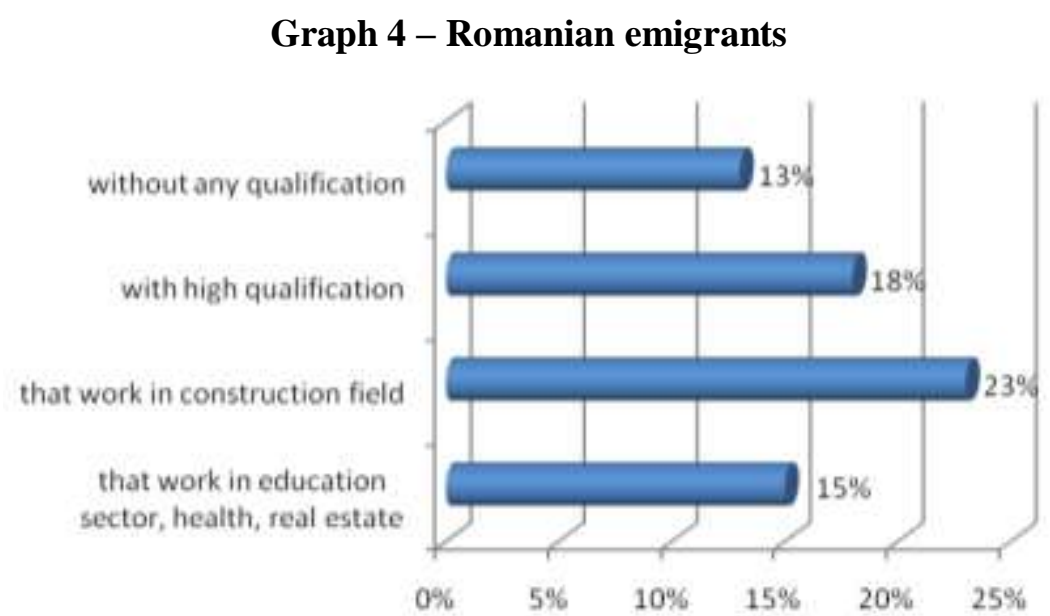

Source: National Institute of Statistics, Romania, 2007

There are fears related to the "young minds" - this flexible and dynamic working force - but it is recognized that the favorite destination countries are determined through the geographical accessibility and/or the presence of existent migratory networks. For example, many countries with which the Office for the Working Force Migration in Romania has signed bilateral agreements, are preferred as destinations by the Romanian. $40 \%$ express their preference to migrate to Italy and Germany (20\% each), followed by Spain, France and Austria and Great Britain is not - and with little probability to become- an important country of destination, although this also depends on the transitory arrangements of other countries and their evolutions and consequences.

\section{Graph 5 - The age of Romanian emigrants}

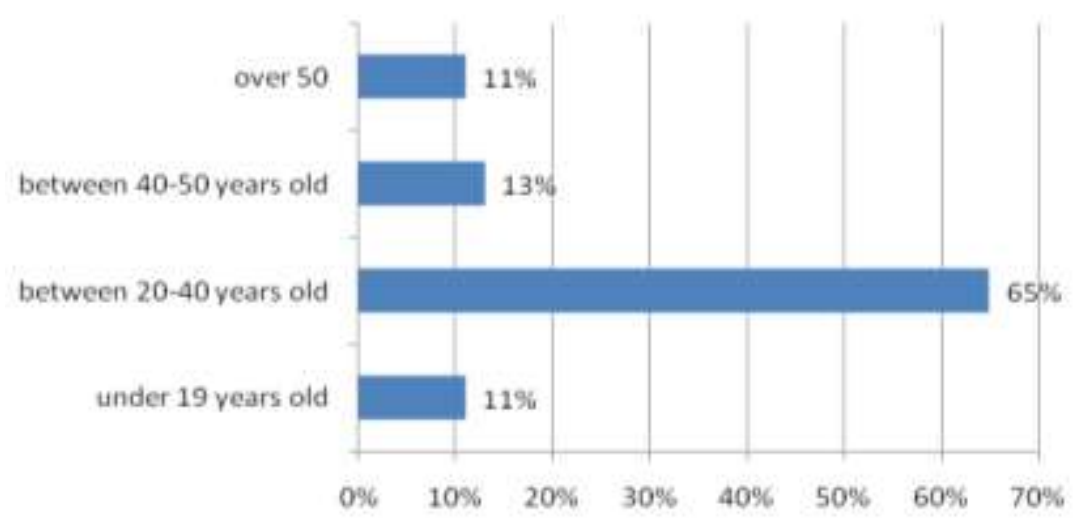

Source: Romanian Academy

We mention that only about 3 - $4 \%$ of the Romanians intend to emigrate abroad for an indefinite period of time, while a higher proportion of the population intends to migrate for a short term, less than a year. 


\section{REASONS FOR MIGRATION}

According to World Bank Report, some of the trends and motivations for migration in the Europe region are similar to those found elsewhere in the world. When addressing issues linked to international migration one has to take into consideration some of the characteristics of this process. First, it is important to be aware of the fact that no country of the world is excluded from the international migration flows. Second, we are now facing new migration attitudes, labour migration and an e-work increase. The third aspect refers to the free movement of persons and labour force $-\mathrm{a}$ component of building up the domestic EU labour market (file package that Romania is negotiating with EU). Finally, there is an increasing need for a better labour force circulation, which can be seen as a de-tensioning mechanism of the local labour markets (in candidate countries) and to diminish the labour market supply deficit (in EU countries or in other developed countries).

The intention to migrate for temporary work abroad occurs much more frequently than the intention to move within the country. This is a clear sign that the propensity for temporary emigration is higher than the propensity for internal migration.

Table 1 - The structure of the migration intentions by residence (\%)

\begin{tabular}{|l|r|r|r|}
\hline \multirow{2}{*}{ reasons for migrating.... } & \multicolumn{2}{|c|}{ Residence } & \multirow{2}{*}{ Total } \\
\cline { 2 - 3 } & rural & urban & \\
\hline $\begin{array}{l}\text { for work abroad and within the } \\
\text { country }\end{array}$ & 2.4 & 2.4 & 2.4 \\
\hline only for work abroad & 8.0 & 11.2 & 9.7 \\
\hline only within the country & 3.7 & 5.8 & 4.9 \\
\hline no & 86.0 & 80.6 & 83.0 \\
\hline Total & 100.0 & 100.0 & 100.0 \\
\hline
\end{tabular}

Source: Public Opinion Barometer, Open Society Foundation, 2004

The two contrasting types of migration - for work abroad and within the country -have common and specific determinants. The younger generation from households with international migration experience is more inclined to migrate within or outside the country. Temporary emigration for work is higher amongst men than women. It is also higher for vocational educated people, for those that travelled abroad and live in rather large localities with high unemployment.

There are different motivations and explanatory factors in the light of major theories of international migration. A lot of studies on migrants stress the importance of economic aspects in building a sustainable motivation for emigration - as cost-benefit or win-win theories (Afoloyan, 
2001, p. 21) with assumption that migration occurs from labour abundant to labour scarce countries (as the supply and demand of labour market related to wage differences).

In the following figures, we can observe the mechanism of the permanent versus temporary migration process and its resorts:

Figure 1 - Permanent migration mechanism

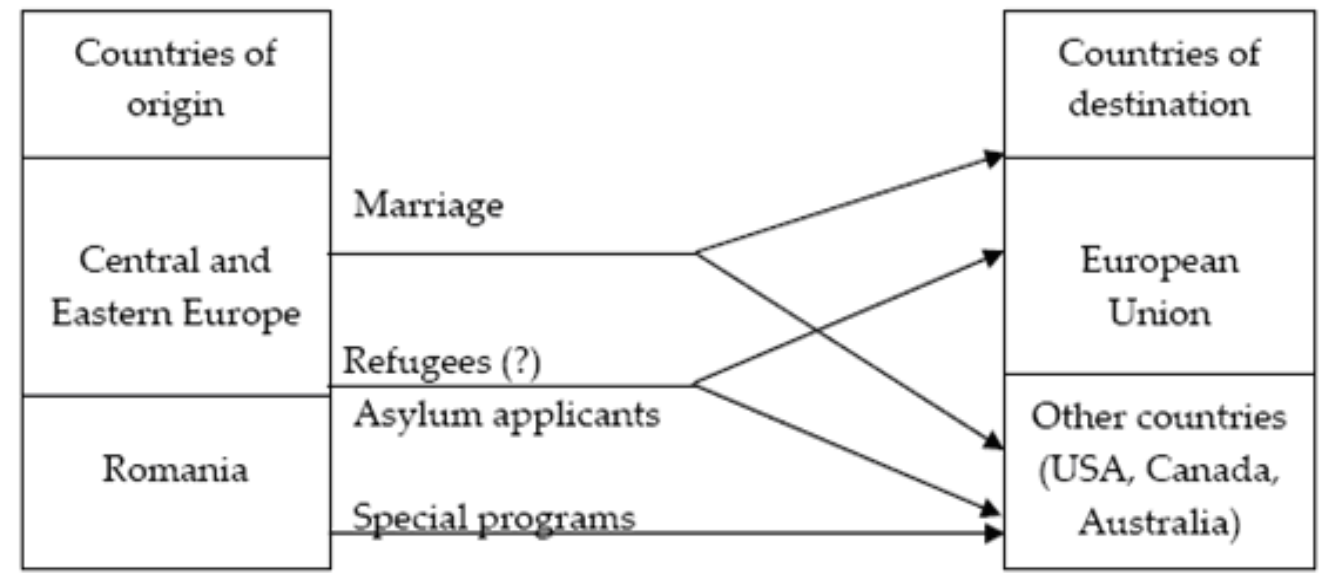

Source: The Romanian Journal of European Studies, nr.4/2005

Figure 2 - The mechanism of legal temporary migration in Europe

\begin{tabular}{|c|c|c|}
\hline $\begin{array}{c}\text { Countries of } \\
\text { origin }\end{array}$ & Students & $\begin{array}{l}\text { Countries of } \\
\text { destination }\end{array}$ \\
\hline $\begin{array}{c}\text { Central and } \\
\text { Eastern Europe }\end{array}$ & Temporary workers & $\begin{array}{l}\text { European } \\
\text { Union }\end{array}$ \\
\hline Romania & $\begin{array}{l}\text { (Bilateral agreements) } \\
\text { Asylum applicants, refugees }\end{array}$ & $\begin{array}{l}\text { Spain, Greece, } \\
\text { Italy, Germany }\end{array}$ \\
\hline
\end{tabular}

Source: The Romanian Journal of European Studies, nr.4/2005 
Mungiu-Pippidi (2005) has realized a study concerning the migration phenomenon and the results are presented in the table 2 :

Table 2 - The migration phenomenon

\begin{tabular}{|l|l|}
\hline SURVEY ITEM & ROMANIA \\
\hline $\begin{array}{l}\text { Temporary migration intention (Do you plan to leave the country temporarily to } \\
\text { seek work abroad?) }\end{array}$ & $12 \%$ \\
\hline $\begin{array}{l}\text { Permanent migration intention (Do you plan to emigrate abroad and to live } \\
\text { there?) }\end{array}$ & $3 \%$ \\
\hline $\begin{array}{l}\text { Personal migration experience (Have you worked abroad during the last } 10 \\
\text { years?) }\end{array}$ & $6 \%$ \\
\hline $\begin{array}{l}\text { Family migration experience/past (Did any member of your household work } \\
\text { abroad for a while?) }\end{array}$ & $14 \%$ \\
\hline $\begin{array}{l}\text { Family migration experience/present (Is anybody from your household currently } \\
\text { working abroad?) }\end{array}$ & $10 \%$ \\
\hline Favoured destination countries & \begin{tabular}{l} 
Italy \\
Spain \\
\hline
\end{tabular} \\
\hline
\end{tabular}

Source: Mungiu-Pippidi, A., 2005

Critics of migration argue that the brain drain and slower labour force growth can retard economic growth in countries of origin. Most migrants do not have jobs in their countries of origin, or have subsistence jobs. Most temporary migrants are actually low skilled workers, and the low skilled jobs they take in countries of destination might otherwise not be filled by local workers.

Certainly, a significant portion of Southeast Europe's economic migrants in the EU work illegally, and some fall victim to trafficking and other forms of exploitation. However, these problems reflect the illiberal visa and work permit regimes pursued by EU countries. These policies unnecessarily damage the interests of migrant workers, reduce the economic benefits of migration, and support the criminal trafficking industry.

One of the most important cause for emigrating is the level of revenues. For having a look concerning the GDP/inhabitant in EU 27, we present the following graphic: 
Graph 6 - GDP/inhabitant in PPS, 2007, EU27=100 ${ }^{3}$

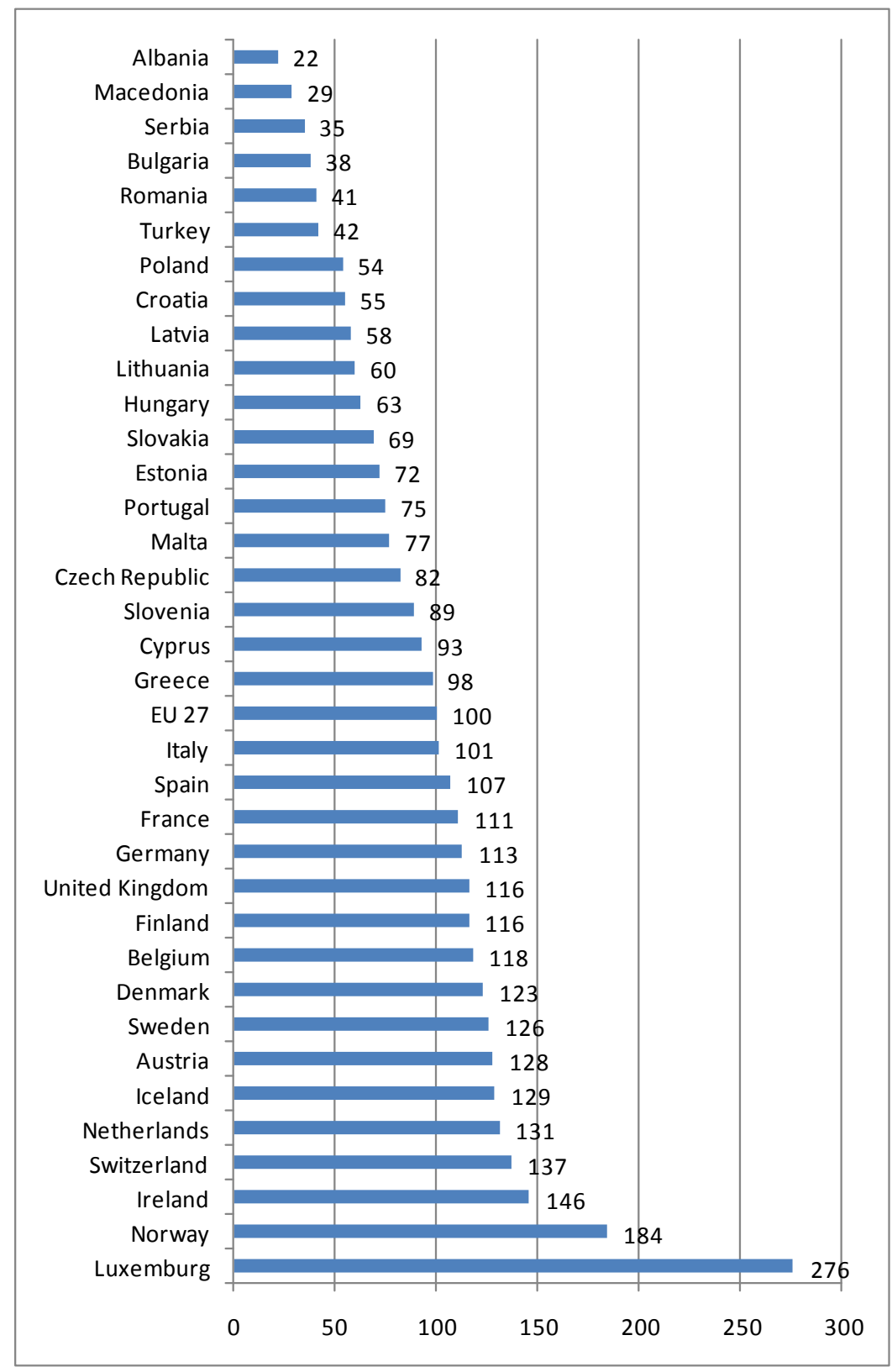

Source: Eurostat, The Statistical Office of the European Communities, 2008

\footnotetext{
${ }^{3}$ Note: Figure covers the 27 EU Member States, the three candidate countries, three EFTA countries and two Western Balkan countries.
} 
Based on first preliminary estimates for 2007, Gross Domestic Product (GDP) per inhabitant expressed in Purchasing Power Standards (PPS) varied from $38 \%$ to $276 \%$ of the average across the EU27 Member States. The Purchasing Power Standard (PPS) is an artificial reference currency unit that eliminates price level differences between countries. Thus one PPS buys the same volume of goods and services in all countries. This unit allows meaningful volume comparisons of economic indicators across countries. Aggregates expressed in PPS are derived by dividing aggregates in current prices and national currency by the respective Purchasing Power Parity (PPP). The level of uncertainty associated with the basic price and national accounts data, and the methods used for compiling PPPs imply that differences between countries that have indexes within a close range should not be over-interpreted.

GDP per inhabitant was around the EU27 average in 2007 in Spain, Italy, Greece and Cyprus. Austria, Sweden, Denmark, Belgium, Finland, the United Kingdom, Germany and France were between $10 \%$ and $30 \%$ above the average, while the highest levels of GDP per inhabitant in the EU were registered in Luxembourg, Ireland and the Netherlands. The high level of GDP per inhabitant in Luxembourg is partly due to the large share of cross-border workers in total employment. While contributing to GDP, they are not taken into consideration as part of the resident population which is used to calculate GDP per inhabitant. Slovenia, the Czech Republic, Malta, Portugal and Estonia were between 10\% and 30\% lower than the EU27 average. Slovakia, Hungary, Lithuania, Latvia and Poland were between $30 \%$ and 50\% lower, while both Romania and Bulgaria were about 60 percent below the EU27 average.

The discrepancies in the wages level represent another major factor of emigration.

Graph 7 The minimum wage (euro)

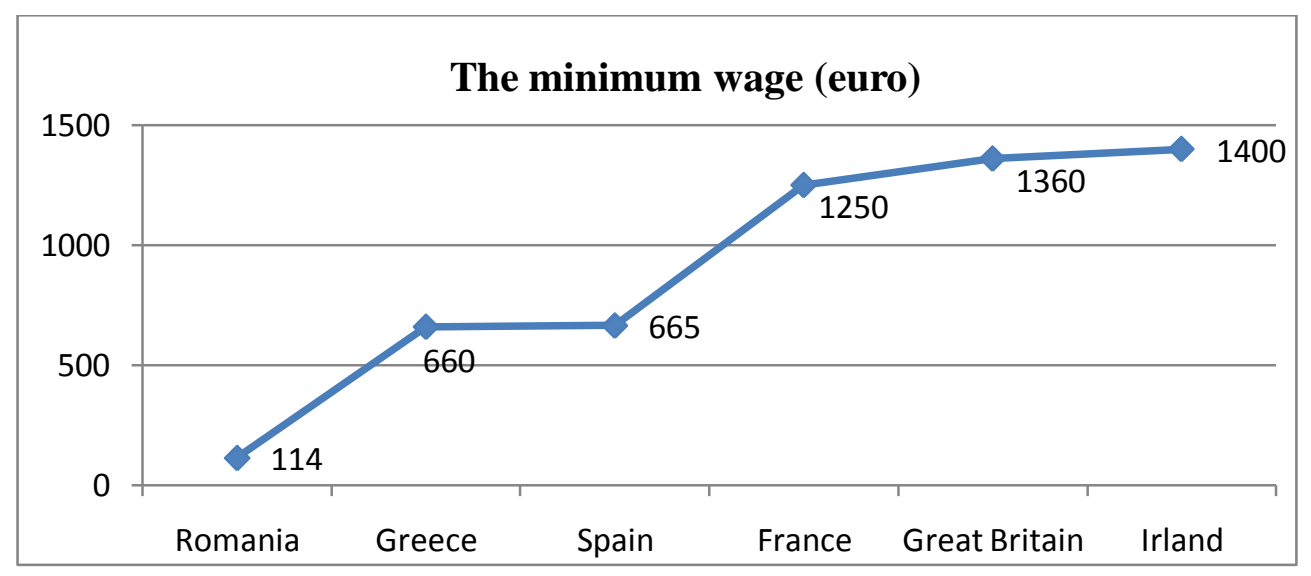




\section{What is happening with Romanians workers?}

Individuals will migrate if the expected utility of moving to an alternative location is greater than the expected utility of remaining in their current location (net of transaction costs). Specifically, holding everything else constant, individuals will migrate to the location which yields them the highest expected earnings (Dostie, L., 2006).

According to The Irish Congress of Trade Unions (2007) predicting the scale of migration from Romania and Bulgaria is not possible. However it is known that there are strong push-up factors at work, Romanian and Bulgarian living standards are lower than any of the 10 countries that joined the European Union in 2004. A simple comparison shows that the monthly minimum wage of April 2005 in Ireland was $€ 1,064$ while in Romania it was $€ 219$ and in Bulgaria $€ 232$. It is also known that there is a strong relation between the number of workers with established contact in Ireland and the number that can be expected to migrate. The increases recorded for Polish and Lithuanian nationals after May 2004 suggests that Romanians and Bulgarians can also be expected to migrate to Ireland. UK government reviewed restrictions imposed on Romanian and Bulgarian workers. The migrants from these countries are allowed into UK if they fall intro one of these categories:

$>$ highly-skilled workers;

$>$ students;

$>$ those with specialist skills which cannot be met by resident labour;

$>$ the self-employed;

$>$ a quota of 20,000 low-skilled workers for the food processing and agriculture sectors.

Romania started the transition process by adopting a gradualist strategy for implementing its economic reforms, most of which being carried out independently and not through a concrete and cohesive policy package, as argued by Staehr (2003). In many respects the stabilization of inflation and budgetary deficit has been used for promoting an illusionary growth that proved to be a huge burden for the population. In the real sector, the government priority consisted of restructuring state-owned enterprises prior to their privatization, instead of closing down the unprofitable companies. Direct and indirect subsidies, generously provided in various forms to public firms, slowed down the process of privatization and discouraged the private incentive. A significant proportion of prices have been kept administratively controlled until 1997, in the detriment of competition.

Bulgarians and Romanians are also free to travel anywhere in the EU. But restricting labourmarket access to EU citizens who can move freely could promote irregular migration. In EU-15 
countries that have placed restrictions, there have been suggestions, from the European Commission among others, of A-8 nationals being subcontracted to get around the restrictions as well as working illegally, either in the informal economy or as supposed "self-employed" workers. Irregular migration from Bulgaria and Romania could lead to the undercutting of local wages, tax avoidance, and exploitation of irregular workers (Drew and Sriskandarajah, 2007)

Substantial efforts have been made to restructure the enterprises but the effective results are still poor, since these efforts have been wrongly directed towards companies without economic perspective. At the same time, the restructuring has been often regarded as a process of improving the technological endowment of enterprises and less attention has been paid to institutional changes and policy measures aimed to adjust the labour market to the new conditions required by a market oriented economy.

\section{EFFECTS OF MIGRATION}

While migration keeps unemployment low and remittances high, shortages in the labour market cause economic losses and create wage pressures for businesses:

- The country's unemployment rate was $6.9 \%$ in June 2007. Although joblessness is growing in certain fields, labour migration is exporting unemployment;

- Remittances from migrant workers represent an important source of Romania's income amounting to US\$4.7 billion in 2005;

- Remittances help improve the standard of living of many Romanian consumers as they increase their purchasing power and stimulate consumer demand for goods and services;

- The gap in the labour market is generating economic losses for businesses as it causes wage pressures and cuts in production volume, especially in the manufacturing and construction sectors. A clothing factory in Romania's textile centre Bacau, for example, hired 670 Chinese workers in April 2007 after failing to attract local staff despite offering double the average minimum wage;

- FDI inflows have been a main driver for Romania's economic growth. Between 2001 and 2006, the country received US $\$ 26.0$ billion in FDI inflows. Foreign businesses were attracted by Romania's skilled labour force and low wages. The labour shortages could now deter them; 


\section{Graphic 8 - Romania FDI inflows and minimum wages 2002-2006}

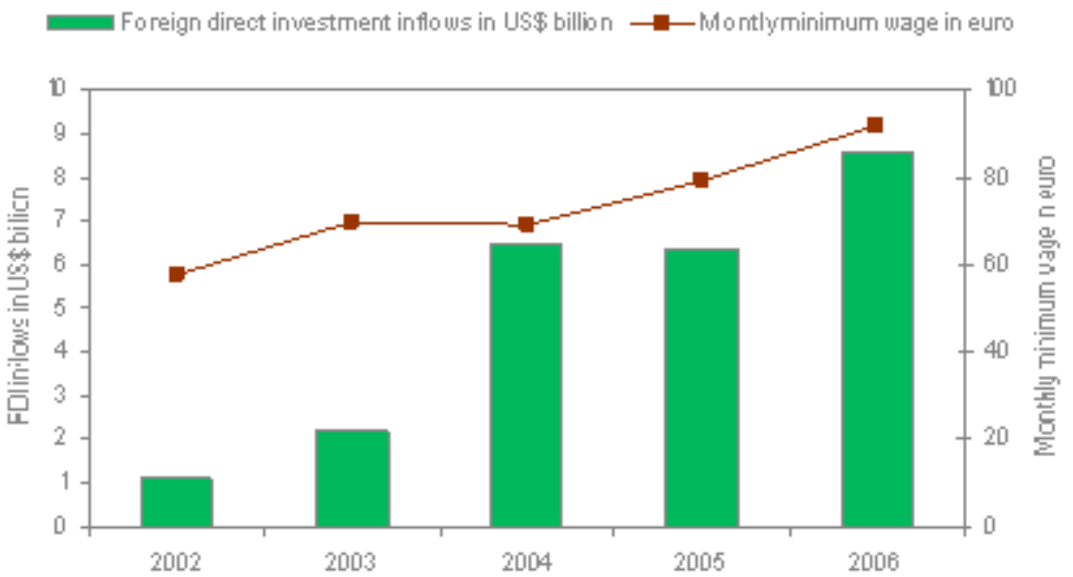

Source: Euromonitor from UNCTAD and Eurostat

- The migration of Romania's labour force concerns mainly skilled white and blue collar workers. The country's labour market is lacking staff in the healthcare, agricultural and construction sector;

- In light of Romania's labour emigration and rising wage pressures, the country will become less attractive to foreign investors, causing the economy to grow at a slower pace. However, increased remittances from abroad will help to raise consumer purchasing power. 
We summarize the main effects of migration in the following table:

Table 4

\begin{tabular}{|c|c|}
\hline The economic effects & $\begin{array}{l}\text { Effects in the plan of the citizen's public } \\
\text { security }\end{array}$ \\
\hline $\begin{array}{l}\text { - Big waves of extra-community migrants in } \\
\text { transit to the countries which especially } \\
\text { belong to the EU 15; } \\
\text { - Excess of working force and possibilities of } \\
\text { increase based on the very cheap working } \\
\text { force of extra-community migrants; } \\
\text { - The access of Bulgarian citizens from the } \\
\text { proximity of Romania for trans-border jobs- } \\
\text { as long as the difference of salaries between } \\
\text { the two counties will be maintained; } \\
\text { - The access of EU25 citizens at the level of } \\
\text { experts, followed by a stagnation of the } \\
\text { access of qualified Romanian youngsters on } \\
\text { the work market of Romania or a minor } \\
\text { increase in this segment at the very most; } \\
\text { - Great probability of returning to the work } \\
\text { market of Romania of the former Romanian } \\
\text { citizens, possibly ethnical emigrant } \\
\text { Hungarians, Jewish and Germans, for the } \\
\text { over-qualification positions; } \\
\text { - The emphasis of the "working force } \\
\text { - Coccupational pyramid, with migrants; } \\
\text { difficult professions, with migrants, from } \\
\text { for example those related to the health care } \\
\text { huted by the massive departure of }\end{array}$ & $\begin{array}{l}\text { - Problems generated by the integration into } \\
\text { the society and the working place; } \\
\text { - The increase of exposal to terrorist attacks, } \\
\text { frequent in countries of EU 15; } \\
\text { - The increase of risks to host transborder } \\
\text { criminality networks; } \\
\text { - The increase of citizens' exposal to the } \\
\text { pressures generated by the social and } \\
\text { economic inequities and inequalities; } \\
\text { - The considerable increase of national and } \\
\text { local expenses with the public security } \\
\text { (police); } \\
\text { - The probability of appearance and } \\
\text { concentration of criminal networks } \\
\text { favored by the absence of control and } \\
\text { evidence of migrants; } \\
\text { - The ideal politics for investing the money } \\
\text { transfer is the initiation of businesses by } \\
\text { the migrant workers who have returned, } \\
\text { using their plus of experience and } \\
\text { migration period; }\end{array}$ \\
\hline
\end{tabular}




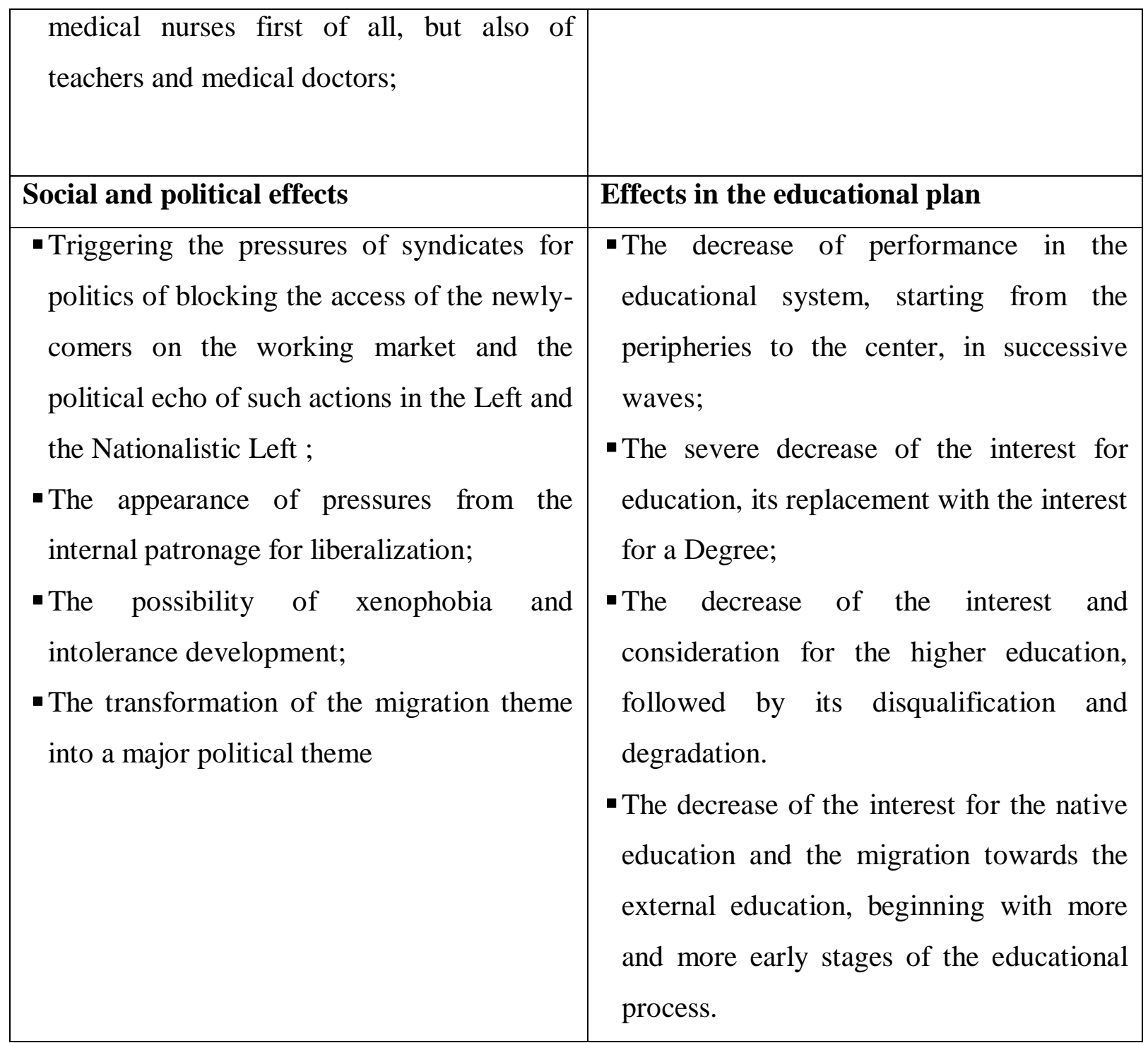

\section{FORECASTING THE EMIGRATION PROCESS}

For the following years, it is estimated that the main destination countries of emigration will be those in the west and south of the EU. The fluxes to Spain or Italy will stagnate, and the Romanians will focus more towards Germany, Ireland or France. The National Agency for the Working Force Occupation in Romania has signed bilateral agreements in the field of the working force exchange, with the following states: Spain, Germany, France, Switzerland, Portugal, Luxembourg, and Hungary. The operational agreements are those signed with Spain, Germany, France and Switzerland. In Italy, Romanians occupy the first place within the legal emigrants, with 555,997 persons, representing $15.1 \%$, being followed by the Moroccans and Albanese, with 387,031, respectively 381,011 persons. For Great Britain, at the beginning of 2007, 1500 working 
permits were awarded, and approximately 8700 persons were registered as independent workers. In Hungary, the percentage of Romanian citizens who are working is of $42 \%$, of a total of foreign citizens of 62000 .

According to the National Office of Labour Force Migration from Romania, reaching a net medium salary of 490 euros, in 2010, would certainly not be sufficient in order to stop the emigration process. If the salaries of Romania reached $40 \%$ of the salary average in the EU, which would suppose to be doubled in three years, the Romanians would no longer be tempted to leave the country. "In the case that the salaries from the country increased satisfactorily in the following years, over $70 \%$ of the Romanians from Italy would return home." According to the same, the Romanians working abroad are currently earning five-ten time more than in the country- between 900 and 1800 euros in constructions and approximately 800 - 900 euros in agriculture. The decision of emigrants to return home depends on numerous factors, among which: the desire to be together with the family, the socio-cultural integration, the language knowledge. Those who left for the money will probably return. However the persons with studies and potential will remain, since they left for the system from that country and for the recognition that they can obtain. In the same time, it estimate that $11 \%$ of the Romanians aged between 18 and 59 years old, would like to leave abroad for work, which means almost 1.5 million persons. In addition, $80 \%$ of the youngsters up to 25 years old declare that they intend to work abroad, in the future. The following destinations of predilection for Romanians will be Ireland, Belgium and Sweden.

The great majority of analysts consider that the Romanians will continue to go to work abroad, in a lower rhythm than the current one, but during the period 2007-2010, the number of people gone will reach the top.

By 2014, all restrictions on the free movement of people within the EU will have been removed, thus, contributing to another wave of labour migration from Romania. Between 2006 and 2020, Romania's population is expected to decrease by $5.7 \%$ from 21.6 million to 20.4 million:

Although Romanian wages are rising, they will remain lower than those in Western European countries, so that migration incentives will remain high for Romanians. Romania's labour exodus is likely to result in the country becoming an attractive destination for migrants from nonEU countries. While businesses will compete for skilled Romanian workers, they will also have the option to employ foreign workers at lower wages. Consumers will rely even more on foreign remittances as wages of unskilled workers will compete with those of foreign migrants.

The analysis of the probable evolution of the activity and employment rate as a whole and by the working age population groups reveals (Vasile, V, 2004): 
The estimated trend is positive and the proposed pace of economic growth requires major labour resources;

$\checkmark$ The variations over the period 2015-2020 are mainly caused by the activity inflows and outflows and the working age group incoming and outgoing of the after-1990 generations;

$\checkmark$ The estimates are quite prudent and with estimated levels under the limits proposed by the EU member countries (70 percent employment rate in 2010, for example). Working age employment rate is estimated to be almost 60 percent in 2010 and 65 percent is 2025;

There is consensus concerning the size of the external labour flows, but at present the size and impact of the East-to-West migration is underestimated. It is quite obvious that such flows will worsen the supply in the national labour market and will be a factor of preconisation of the labour market since Romania's role as a country of transit towards the developed countries in Western Europe will be more significant (especially after the integration, when it becomes the eastern border of the EU).

\section{Graph 9}

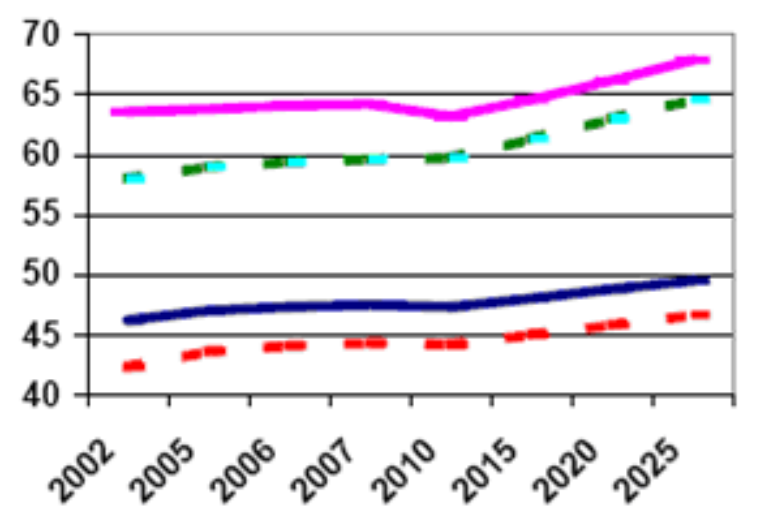

Activity rates and employment rates (projections for the period 2005-2025)

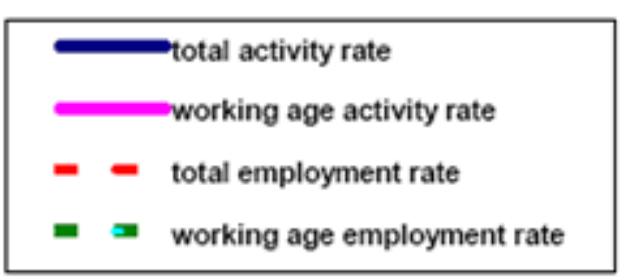

Source: NCF data

Thus, the long-term forecast indicates a higher relative number of employed population that is a higher employment rate. The 2025 estimate employment rate of about 47 percent is lower than the EU objectives. Similarly, the employment rate of the working age population will not exceed 65 percent. 


\section{Graph 10}

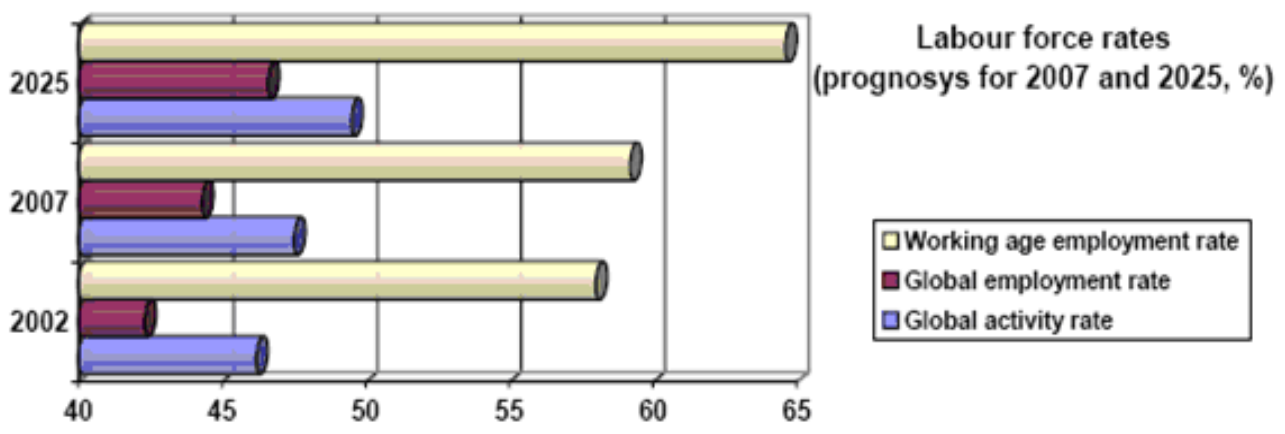

Source: NCF data

The NCF forecast concerning Romania's work potential reveals the possible evolution and, in comparison with the objectives set by The Lisbon Treaty, the size of the gaps on medium term (just before integration) and long term.

Table 5 - The evolution of the labour market potential indicators in Romania (as against $2002=100$ percent)

\begin{tabular}{|l|l|l|}
\hline & $\mathbf{2 0 0 7 / 2 0 0 2}$ & $\mathbf{2 0 2 5 / 2 0 0 2}$ \\
\hline 1.Working age population (15-64 years) & 99.7 & 84.3 \\
\hline 2. Inactive population of 15-64 years & 99.2 & 76.4 \\
\hline 3. Available labour resources (row 1 - row 2) & 99.9 & 88.8 \\
\hline 4.Total active population & 100.9 & 96.8 \\
\hline 5. Total employed population & 102.8 & 99.4 \\
\hline 6. ILO unemployment & 80.5 & 68.6 \\
\hline 7. Labour shortage (row 3 - row 4) & 117.2 & 232.7 \\
\hline
\end{tabular}

Source: NCF data

While the total active population grows slightly up to 2007, in 2025 we will face contingents of all population categories under the 2002 level. Even if the estimates show a diminution in the inactive population by one quarter and in the unemployment rate to 5-6 percent, the available labour resources will be 12 percent smaller in 2025 and the labour shortage will worsen substantially (by 17 percent in 2007 and over 2.3 times in 2025). While the labour shortage is calculated by correlating the expected economic growth with the potential labour productivity, then it will be even worse. The shortage covering by labour force from outside the working age group, especially 
pensioners may cope with the additional needs. The domestic human resources will not be enough to cope with the proposed high rate of development.

\section{What can we do?}

Romania's government has undertaken a number of initiatives in order to tackle the labour crisis and encourage Romanians to stay or return to the country:

$>$ In November 2006, an inter-agency working group was set up to devise a strategy for informing Romanians abroad of improved wage conditions;

For 2007, the healthcare and education sectors have been granted an increase in wages of $20 \%-24 \%$ from the state budget.

Also, the Romanian government plans to spend EU structural funds on rural development. According to its National Action Plan for Employment from July 2006, it intends to create 140,000 jobs and undertake professional training of 15,000 people in rural areas, which will help regional development.

As this is possible gradually and to a small extent on the short term, the priorities should be:

a) The politics for elaborating and applying some fiscal facilities schemes meant to encourage, according to the allotted capital, productive investments, generating new jobs (Currently, about two thirds of these capital fluxes go the consume)

b) Public-private partnership politics fiscally simulative, with the investor local administrators, for the common achievement of local investments, which could bring profit, with the management ensured by workers with community experience.

c) Stimulating politics for medium and long-term placements as efficiently as possible, in impact fields; systematic information, assistance and counseling of migrants in knowing and evaluating the possibilities of investment.

Politics for creating the necessary instruments for the use of the banking system, under the conditions of accessible commissions, for the transfer of remittances, in the detriment of informal transfers (which reach $40 \%$ of the sums sent to the country). Greece and Portugal, countries that have massively exported working force in the past, have taken measures in this regard. The national banks have opened branches in the destination countries where the majority of their co-nationals were working. The services included costs guaranteed by the governments, with an attractive interest rate and facilities for stimulating the investments in the countries of origin. 


\section{CONCLUDING REMARKS}

Romania, one of the poorest nations in Europe, faces critical challenges in its efforts to implement labour market and social programmes similar to those found in more developed countries. Poverty is widespread and the economy requires major restructuring while a substantial number of households still depend on subsistence farming and other informal economic activities for survival. Increasing expenditures on social insurance is not a viable option as Romania already charges some of the highest payroll contribution rates in the world.

The present social challenges are closely intertwined with a highly distorted economy. Romania will receive through the European Social Fund co-financing worth 3.68 billion euro in order to create new jobs and to improve the existing ones. The programs involved in the project refer to improving personal skills, improving public services and creating a more efficient and effective public administration in the country. The European Social Fund recognises the importance of enabling workers and businesses to adapt to a changing economy and will be helping people gain the skills they need to become employed or stay in work.

Clearly, the top priority must be the modernisation of the economy with the provision of a comprehensive social safety net in the face of potentially higher unemployment.

It is time to think of the Romanian labour force as a valuable resource and to treat it accordingly - from the point of view of remuneration, of working conditions, of rights and liberties, of investment in the development of human resources and of vocational and educational training, in accordance with the requirements of the labour market. All of these in the context in which human migration affects population patterns and characteristics, social and cultural patterns and physical environments as people move, their cultural traits and ideas with them, creating and modifying cultural landscapes. Romania must no longer use cheap human capital as a means of becoming more competitive.

\section{REFERENCES}

Afolayan, A. (2001), Issues and Challenges of Emigration Dynamic in Developing Countries, International Migration, Blackwell Publisher Ltd, Oxford, vol. 39, no. 4, pg. 5-38.

Cindrea, I, (2007), The Crisis on the Labour Market in Romania, Theoretical and Applied Economics, vol. 4, no. 509, pg. 25-28. 
Dolton, P., O'Neill, D. (2002), The Long-Run Effects of Unemployment Monitoring and Work Search Programmes, The Journal of Labour Economics, no. 20.

Drew, C., Sriskandarajah, D. (2007), EU Enlargement in 2007: No Warm Welcome for Labour Migrants, at http://www.ippr.org/articles/index.asp?id=2503.

Favel, A., Hansen, R. (2002), Markets against politics: Migration, European Union Enlargement and the Idea of Europe, Journal of Ethnic and Migration Studies, vol. 28, no.4, pp. 581601.

Gangl, M. (2006), Education and Labour Market Entry across Europe: The Impact of Institutional Arrangements in Training Systems and Labour Markets. Working Papers, Arbeitspapiere.

Garson J.P. (2004), Migration in Europe: Trends and Perspective, Keynote Report, at http://www.jil.go.jp/foreign/event_r/event/documents/2004sopemi/2004sopemi_e_session2 .pdf.

Hatton, T., Williams, J. (1998), The Age of Mass Migration, Oxford University Press.

Lazaroiu, S. et al. (2003), Migration Trends in Selected Applicants Countries, vol. IV - Romania, More 'Out' than 'In' at the Crossroads between Europe and the Balkans, International Organization for Migration, Vienna.

Maré, D., Timmins, D. (2000), Internal Migration And Regional Adjustment: Some Preliminary Issues.

Mungiu-Pippidi, A. (2005), Seeking The Virtuous Circle: Migration and Development In South Eastern Europe, Review Migration and development, no. 2.

Potot, S. (2000), Mobilites en Europe. Etudes de deux reseaux migratoires roumains, Romanian Sociology, no. 2, pp. 101-121.

Sandu, D. et. al. (2004), A Country Report on Romanian Migration Abroad: Stocks and Flows After 1989, Multicultural Centre Prague.

Shields, M., Wheatley P.S. (1998), The Earnings of Male Immigrants in Britain, Applied Economics, no. 30, pp. 1157-68.

Sriskandarajah, D. (2006), Pulling up the drawbridge will damage our economy, The Guardian.

Vasile, V. (2004), Demographic Changes and Labour Market in Romania Institute of National Economy, Romanian Academy, at http://www.oecd.org/document/23/0,3343.

Vasile, V. (2004), Demographic Changes and Labour Market in Romania, INE.

Wallace, C., Stola, D. (2000), Introduction: Patterns of Migration in Central Europe, in Wallace, C., Stola, D. (eds.) Patterns of Migration in Central Europe, Palgrave Macmillan. 
Wheatley P.S. (2001), The Employment Adjustments of Male Immigrants in England, Journal of Population Economics, no. 14, pp. 193-220.

Zaman, C. (2004), Labour market efficiency over the transitional period: the case of Romania, at http://papers.ssrn.com/sol3/papers.cfm?abstract_id=625061.

http://dissertations.ub.rug.n1/FILES/faculties/rw/2004/r.p.w.jennissen/titlecon.pdf

http://ec.europa.eu/justice_home/doc_centre/asylum/statistics/docs/2003/countryreports/romania.pdf

http://www.euromonitor.com/Romanian_migration_raises_concerns_over_labour_shortage

http://www.romanianewswatch.com/2007/06/migration-review-by-september.html

http://www.sfos.ro/en/program_articol.php?articol=54

http://www.mie.ro/stiri_en.php?s=217\&lang=en 